Original Article

\title{
Knowledge on Vitamin D Deficiency among Antenatal Women in a View to Prepare Information Guide Sheet
}

\author{
Anishlyn R ${ }^{1}$, Anna Punnose ${ }^{2}$, Josephine Khonja ${ }^{3}$, Shiji PJ ${ }^{4}$, Precilla D'Silva ${ }^{5}$ \\ ${ }_{1,2,3}$ Student, B.Sc Nursing, ${ }^{4}$ Associate Professor, Community Health Nursing Department, ${ }^{5}$ Lecturer, Obstetrics and \\ Gynecological Nursing Department, Father M uller College of Nursing, Father M uller Road, Kankanady, M angaluru. \\ Corresponding Author : Precilla D'Silva, Lecturer, Department of OBG Nursing, Father M uller College of Nursing, Father Muller Road, \\ Kankanady, M angaluru - 575002, M obile : +9197318 73891, E-M ail : precilladsilva25@ fathermuller.in
}

Received

: 25.02.2018

Review Completed : 12.06.2018

Accepted

: 13.07.2018

Keywords : Vitamin D deficiency, antenatal women, pamphlet

\begin{tabular}{|c|}
\hline Access this article online \\
\hline Quick Response Code \\
\hline \\
\end{tabular}

\begin{abstract}
:
Vitamin $D$ is essential to maintain bone health, playing a key role in bone mineralization. Severe vitamin $D$ deficiency in children results in rickets. As stores of vitamin $D$ in newborns are dependent on maternal vitamin D status, vitamin D deficiency during pregnancy leads to infant vitamin D deficiency and thus increases risk of rickets.
\end{abstract}

Objectives: To assess the know ledge regarding Vitamin D deficiency and to find the association of knowledge score and demographic variables.

\begin{abstract}
Materials and Methods: A descriptive approach was adopted for this study. The study was conducted in OBG outpatient department of tertiary Hospital at Mangaluru. The study sample was 100 antenatal women. A knowledge questionnaire was used to collect the data regarding knowledge on vitamin $D$ deficiency.

Result: In this study $65 \%$ of antenatal women had average knowledge, $34 \%$ antenatal women had poor knowledge and single antenatal women had good knowledge on vitamin $D$ deficiency. The knowledge in the area of complication to the fetus was $38 \%$, knowledge in the other areas were daily requirements $56 \%$, prevention $52 \%$ and signs and symptoms $48 \%$.

Interpretation and conclusion: After conducting the study the result showed that, majority of the antenatal women had average knowledge regarding vitamin $D$ deficiency. For further improvement of the knowledge, antenatal women were provided with an information guide sheet (pamphlet).
\end{abstract}

\section{Introduction}

Vitamin D is an essential vitamin to the body, to such an extent that medical professionals call it the "super nutrient". A steroid vitamin which promotes the intestinal absorption and metabolism of calcium and phosphorus. ${ }^{1}$ Vitamins are micronutrients required in small quantity for the proper functioning of the body. ${ }^{2} \mathrm{M}$ aternal vitamin $\mathrm{D}$ deficiency is associated with detrimental effects on the fetus / infant as well as complications for the mother during pregnancy. Fetal and neonatal risks include intrauterine growth retardation, neonatal hypocalcemic seizures, impaired postnatal growth, rickets in infancy and cardiomyopathy and bone mineralization in later life of period. ${ }^{1}$ Complications of vitamin $D$ deficiency include Rickets, Osteoporosis, Depression Fatigue, Hyperparathyroidism, Obesity, Osteomalacia, Chronic Backache, Hypertension, cancers, chronic pain, diabetes, multiple sclerosis or heart disease. ${ }^{3}$ Lower levels of vitamin $D$ in mother have been associated with increased rates of cesarean delivery, bacterial vaginosis and pre eclampsia as well as less efficient glucose metabolism. ${ }^{1,4}$ Vitamin D receptors in uterine muscle could affect contractile strength, and vitamin $D$ has been shown to have immune modulatory effects, thereby potentially protecting the host from infection. ${ }^{1}$ Vitamin $D$ is widely available in the sunlight. ${ }^{1,3,5}$ Foods that contain Vitamin D include oily fish, cod liver oil, egg yolk and liver. ${ }^{2}$ Vitamin $D$ deficiency can be preventable. ${ }^{4}$ Causes for vitamin D deficiency include: use of sun creams, less exposure to sunlight, use of closed clothing's and increased time spent for indoor games. ${ }^{4}$ There are two forms of vitamin D. Vitamin D3 (cholecalciferol) is produced from the conversion of ${ }^{7}$. dehydrocholesterol in skin and vitamin $D^{2}$ (ergocalciferol) is produced in mushrooms and yeast. The biologically active 
form of vitamin $D$ is $1,25(\mathrm{OH}) 2 \mathrm{D}$. ${ }^{6}$ There is no enough data which supports that all the pregnant mothers should undergo screening for vitamin $D$ deficiency unless they have some of the complications. Also the test is very expensive which cannot be affordable by all the economic groups. ${ }^{6}$ Low levels of vitamin $\mathrm{D}$ have also been associated with several mental disordersincluding depression.?

\section{Materials and Methods}

A descriptive design is used to conduct the study at outpatient department of tertiary hospital at Mangaluru, Karnataka, India from 10/05/2016 to 29/06/2016 consisting of 100 antenatal women.

Inclusion criteria: Antenatal women with age group of above 18 years with $12-40$ weeks of gestation were the subjects for the study.

Exclusion criteria: Women who are seriously ill and having psychological problems.

\section{Materials and Methods}

Assessment of knowledge regarding vitamin $D$ deficiency was done using a questionnaire. Each correct response was scored as one and wrong answer as zero. The maximum score was 20 and minimum was zero. Along with this the basic proforma was also collected from the respondents. The items in the knowledge questionnaire were divided into sources of vitamin $D$, daily requirements, factors influencing vitamin D deficiency, signs and symptoms of vitamin D deficiency, Complication to mother and fetus and prevention of vitamin $\mathrm{D}$ deficiency.

\section{Results}

The following table shows the demographic variables

Table1 : Distribution of demographic variables in percentage $n=100$

\begin{tabular}{|c|l|l|c|}
\hline SI No & Variables & Categories & percentage \\
\hline \multirow{3}{*}{1} & Age in years & $19-23$ & 40 \\
\cline { 3 - 4 } & & $24-28$ & 37 \\
\cline { 3 - 4 } & & $29-33$ & 16 \\
\cline { 3 - 4 } & & $34-38$ & 7 \\
\cline { 3 - 4 } & & $>38$ & 0 \\
\hline \multirow{2}{*}{2} & \multirow{2}{*}{ Number of children } & One child & 38 \\
\cline { 3 - 4 } & & Two children & 43 \\
\cline { 3 - 4 } & & Three children & 14 \\
\cline { 3 - 4 } & & No children & 5 \\
\hline
\end{tabular}

\begin{tabular}{|c|c|c|c|}
\hline SI No & Variables & Categories & percentage \\
\hline \multirow[t]{5}{*}{3} & \multirow{5}{*}{ Education level } & No education & 15 \\
\hline & & Pimary & 29 \\
\hline & & Secondary & 29 \\
\hline & & Graduate & \\
\hline & & or post graduate & 27 \\
\hline \multirow[t]{2}{*}{4} & \multirow{2}{*}{ Working status } & Yes & 19 \\
\hline & & no & 81 \\
\hline \multirow[t]{4}{*}{5} & \multirow[t]{4}{*}{ Income per month } & $4500-6500$ & 33 \\
\hline & & $6501-8500$ & 36 \\
\hline & & $8501-10500$ & 21 \\
\hline & & $>10501$ & 10 \\
\hline \multirow[t]{3}{*}{6} & \multirow[t]{3}{*}{ Type of family } & Nuclear & 51 \\
\hline & & Joint & 36 \\
\hline & & Extended & 13 \\
\hline \multirow[t]{2}{*}{7} & \multirow[t]{2}{*}{ Eating habits } & Vegetarian & 31 \\
\hline & & Mixed & 69 \\
\hline \multirow[t]{2}{*}{8} & \multirow{2}{*}{$\begin{array}{l}\text { Daily exposure to } \\
\text { sunlight }\end{array}$} & yes & 61 \\
\hline & & no & 39 \\
\hline \multirow[t]{3}{*}{9} & \multirow[t]{3}{*}{ Exposure time limit } & $0-15$ mins & 33 \\
\hline & & $16-30$ mins & 24 \\
\hline & & $>31$ mins & 4 \\
\hline \multirow[t]{2}{*}{10} & \multirow{2}{*}{$\begin{array}{l}\text { Intake of calcium } \\
\text { during pregnancy }\end{array}$} & Yes & 73 \\
\hline & & no & 27 \\
\hline
\end{tabular}

\section{Overall knowledge of antenatal women regarding vitamin Ddeficiency}

Table 2: Frequency and Percentage Distribution of Subjects According to the Grading of Knowledge Score $n=100$

\begin{tabular}{|l|l|l|c|c|}
\hline $\begin{array}{l}\text { Knowledge } \\
\text { score }\end{array}$ & Grading & $\begin{array}{l}\text { Range of } \\
\text { percentage }\end{array}$ & $\begin{array}{c}\text { Frequency } \\
\text { (f) }\end{array}$ & $\begin{array}{c}\text { Percentage } \\
\text { (\%) }\end{array}$ \\
\hline $0-7$ & Poor & $<33 \%$ & 34 & 34 \\
\hline $8-14$ & Average & $34-66 \%$ & 65 & 65 \\
\hline $15-20$ & Good & $67-100 \%$ & 1 & 1 \\
\hline
\end{tabular}

M aximum Score $=20$

Table 2 : Mean, Mean Percentage and Standard Deviation of Knowledge on vitamin D deficiency among antenatal women

$\mathrm{n}=100$

\begin{tabular}{|l|l|l|l|}
\hline Variable & Max. score & Mean \pm Standard deviation & Mean $\%$ \\
\hline $\begin{array}{l}\text { Knowledge } \\
\text { score }\end{array}$ & 20 & $9.03 \pm 3.138$ & $45.15 \%$ \\
\hline
\end{tabular}

Table 3 : Association between knowledge on vitamin D deficiency and demographic variables

$\mathrm{n}=100$

\begin{tabular}{|c|l|c|c|c|}
\hline SI No & Variable & $\geq$ median & $<$ median & $\chi^{2}$ \\
\cline { 1 - 4 } 1 & Age in years & & & \multirow{2}{*}{0.150} \\
\cline { 1 - 3 } & $19-23$ & 20 & 20 & \\
\cline { 1 - 3 } & $24-28$ & 18 & 19 & \\
\cline { 1 - 3 } & $29-33$ & 2 & 5 & \\
\hline & $34-38$ & 10 & 6 & \\
\hline
\end{tabular}




\begin{tabular}{|c|c|c|c|c|}
\hline SI No & Variable & $\geq$ median & $<$ median & $\chi^{2}$ \\
\hline \multirow[t]{5}{*}{2} & Number of children & & & \multirow[t]{5}{*}{0.686} \\
\hline & One child & 18 & 21 & \\
\hline & Two children & 21 & 22 & \\
\hline & Three children & 9 & 5 & \\
\hline & No children & 2 & 2 & \\
\hline \multirow[t]{5}{*}{3.} & Education & & & \multirow[t]{5}{*}{0.18} \\
\hline & No education & 4 & 11 & \\
\hline & Primary education & 14 & 15 & \\
\hline & Secondary education & 21 & 8 & \\
\hline & Graduate or postgraduate & 11 & 6 & \\
\hline \multirow[t]{3}{*}{4} & Working status & & & \multirow[t]{3}{*}{0.202} \\
\hline & Yes & 12 & 7 & \\
\hline & No & 38 & 43 & \\
\hline \multirow[t]{4}{*}{5} & Type of family & & & \\
\hline & Nuclear & 27 & 24 & \\
\hline & Joint & 18 & 18 & \\
\hline & Extended & 5 & 8 & \\
\hline \multirow[t]{3}{*}{6} & Eating habits & & & \multirow{3}{*}{0.017} \\
\hline & Vegetarian diet & 21 & 10 & \\
\hline & Mixed diet & 29 & 40 & \\
\hline \multirow[t]{3}{*}{7} & Sun exposure & & & \multirow{3}{*}{0.599} \\
\hline & Yes & 21 & 10 & \\
\hline & No & 29 & 40 & \\
\hline \multirow[t]{5}{*}{8} & Time limit & & & \multirow{5}{*}{0.637} \\
\hline & No expose & 21 & 21 & \\
\hline & 0-15 minutes & 17 & 13 & \\
\hline & $16-30$ minutes & 11 & 13 & \\
\hline & 31 \& above & 1 & 3 & \\
\hline \multirow[t]{3}{*}{9} & $\begin{array}{l}\text { Received prior information } \\
\text { on vitamin D }\end{array}$ & & & \multirow[t]{3}{*}{0.398} \\
\hline & yes & 30 & 34 & \\
\hline & no & 20 & 16 & \\
\hline \multirow[t]{6}{*}{10} & Source of information & & & \multirow[t]{6}{*}{0.383} \\
\hline & Family members & 6 & 7 & \\
\hline & Friends and family & 9 & 12 & \\
\hline & Mass media & 10 & 5 & \\
\hline & Health personnel & 19 & 15 & \\
\hline & Any other & 6 & 11 & \\
\hline \multirow[t]{3}{*}{11} & $\begin{array}{l}\text { Calcium intake during } \\
\text { pregnancy }\end{array}$ & & & \multirow[t]{3}{*}{0.708} \\
\hline & yes & 38 & 35 & \\
\hline & NO & 12 & 15 & \\
\hline
\end{tabular}

\section{Discussion}

\section{M ajor findings of the study}

\section{Description of baseline proforma according to the sample} characteristics

Highest percentage ( $40 \%$ ) of antenatal women belonged to the age group of $19-23$ years, $37 \%$ belongs to the age group of $24-27$ years, whereas least percentage $(7 \%)$ comes in the age group of 34-38 years. Forty three percentages of antenatal women had 2 children, $38 \%$ had single child, whereas $5 \%$ were primigarvid. Similar percentage $(29 \%)$ of antenatal women was educated till primary and secondary education, but $15 \%$ of samples were not having formal education. Majority of antenatal women (81\%) were housewives and small population (19\%) were working women. $10 \%$ were professional workers and $7 \%$ were non professional workers.

Half of the samples (51\%) belonged to nuclear family, $36 \%$ joint family and $13 \%$ were having extended family. M ost of the antenatal women $69 \%$ were consuming mixed diet and $31 \%$ were consuming vegetarian diet. Sixty one percentages of antenatal women were exposed to sunlight among that $30 \%$ exposed for $0.1-15$ minutes, $24 \%$ for $16-30$ minutes and 39\% revealed that they are not exposed to sunlight. Majority of antenatal women (64\%) had prior knowledge regarding vitamin $D$ deficiency. Thirty four percentage of population had gained knowledge from health personnel \& $22 \%$ gained from friends and neighbors. M ost of the population (73\%) were consuming calcium tablet during pregnancy where as $27 \%$ are not consuming calcium tablets.

A systematic review done in Cochrane library using 7 relevant studies infers that there is no enough evidence to evaluate the requirements and effects of vitamin $D$ supplementation during pregnancy. Data collected from 463 women from three trails showed the result in terms of birth weight falling to 2500 grams than those women who received no treatment or on placebo. Although the statistical significance was borderline. ${ }^{4}$

A cross sectional study conducted in Riyadh, Saudi Arabia to assess the knowledge and practice of vitamin $D$ deficiency revealed the following results: Majority of participants (93.1\%) knew that vitamin $D$ is essential for bone health. Only $66.3 \%$ of the participants revealed that muscle pain related to vitamin D deficiency. However, $48.8 \%$ of our subjects believed that vitamin D deficiency is related to other diseases like: cardiovascular, diabetes, depression, hypercholesterolemia, cancer and multiple 
sclerosis, versus $14.9 \%$ believed there is no relationship exists with the exposure of sunlight and vitamin D synthesis and $36.7 \%$ of the participants did not know the relationship at all. It was interesting that majority of participants $(89.3 \%)$ would like to do vitamin D test. ${ }^{5}$

\section{Overall knowledge of antenatal women regarding vitamin D deficiency}

The present study results showed that $56 \%$ of the samples are aware of daily requirements, $52 \%$ of the samples have knowledge on prevention of complications, $48 \%$ of samples are aware of the signs and symptoms and sources, where as the knowledge regarding complication to mother and fetus were $42 \%$ and $38 \%$.

\section{References}

1. Kavitha D, Anjalakshi C, Prabhu, Rukmani J, R.M. Knowledge, Attitude AndPractice Regarding Vitamin D Deficiency Among Antenatal M others InTamilnadu. Asia Pacific Journal of Research.2015; I. Issue (Xxxi) Available from: www.japsonline.com/admin/php/uploads/ 1387-pdf-pdf

2. Nayana, U J, Planned teaching program creates awareness regardingprevention of Vitamin-D and Calcium deficiency in Children, IJCRR; 2 (4)2014 Apr, 56-64. Available from: www.ncbi.nlm.nih.gov, pubmed/25970148

3. Habib FM, Al-Motairi WA, Al-Mutairi WM, Vitamin D Deficiency:Knowledge and Practice among Adult Saudi Females. Global AdvancedResearch Journal of M edicine and M edical Science. 2014 May, 3(5), 095-101. Available from: file:///c:/ users?download / vitamin $\% 20$ d\%20deficiency\%20knowledge\%20and\%20practice $\% 20$ among\%20adult20saudi\%20femsles.pdf

4. Kaushal M, Magon N. Vitamin D in pregnancy A metabolic outlook. Indianjournal of Endocrinology and Metabolism.2013.Feb17 (1).7682. Available from: www.ncvi.nlm.nih.gov/pubmed/23776856

\section{Association between knowledge on vitamin D deficiency and demographic Variable}

There is no association found with demographic variables and knowledge score except with eating habits ( $p=0.017$ ), hence null hypothesis is accepted. Chi square test was used to identify the association of knowledge on vitamin $D$ and demographic variables. Calculated $p$ value was greater than 0.05 except for eating habits, which indicated no association between vitamin $\mathrm{D}$ deficiency and demographic variables.

\section{Summary}

The findings of this study and other studies show that antenatal women are having limited knowledge on vitamin D deficiency.

5. Babelghaith DS. Wajid S. Zaaqi AAM . Al M alki SA. Al Amri DF. Alfady S. Alghadeer S. Alarifi NM. Knowledge and practice of vitamin D deficiency among people lives in Riyadh, Saudi Arabia- A cross sectional study. Biomedical Research (2017) Volume 28, Issue Available from: http://www.biomedres.info/biomedicalresearch/knowledge-and-practice-of-vitamin-d-deficiency-amongpeople-lives-in-riyadh-saudi-arabiaa-crosssectional-study.html

6. Vitamin D in pregnancy. Scientific impact paper No 43, Royal College of Obstetricians and Gynecologists)une 20014, Available from: https://www.rcog.org.uk/globalassets/documents/guidelines/scienti fic-impact-papers/vitamin d sip43 june14.pdf

7. Accortt EE. Schetter DC. Peters M R. BushrowEA. Lower Prenatal Vitamin D status and postpartum depressive symptomatology in African American women: Preliminary evidence for Moderation by Inflammatory Cytokines .Arch Women's Ment Health. 2016 Apr 19(2):373-383. Available from: https://www.ncbi.nlm.nih.gov/pmc /articles/PM C4801760/pdf/nihms726509.pdf 